\title{
QUALITY OF LIFE USING MUSIC THERAPY ELEMENTS FOR PEOPLE WITH INTELLECTUAL DISABILITIES
}

\author{
Aldona Moceviciene \\ Ilga Prudņikova \\ Rēzeknes Augstskola
}

\begin{abstract}
Quality of life include all aspects of the way we live our lives. They allow us to fulfil our needs and aspirations. On the basis of results of the research possibile to make a confirmation that music, sociocultural activities using music therapy elements for people with intellectual disabilitiess influented expanding possibilities self-expression, activating selfaction, stimulating self-conception. Said elements of socialization impowering those people self - realizing through cultural — artistic activities, sociocultural projects. That one componded efective ,normal" and intellectually disabledcitizens communication and cooperation. Thus possible life quality optimization for people with mental deseases in abilities limited space.
\end{abstract}

Keywords: Quality of life, individuals with moderate to profound intellectual disability, music therapy, self-assessment, self-esteem and self- realization, independent, safe environment, social exclusion.

\section{Introduction}

It is necessary to ensure equal opportunities for everyone to achieve a higher quality of life. Quality of Life - a term, covering various aspects of life and in the various fields of science: geography, philosophy, medicine, social sciences, health promotion and advertising (Oort, Visser and Sprangers, 2005). The model which presents Lindströ (Lindströ, 1994) the quality of life includes four areas of life: global, external, interpersonal and personal sphere. The last part of model symbolize the physical, mental and spiritual dimensions of quality of life. Rakauskienè and Servetkevičienè (Rakauskienè, Servetkevičienė, 2011) presented concept is multidimensional and integrates ecological, economic, material and spiritual and moral health development of society.

World Health Organization, in defining the concept of quality of life, finds that it is a wide concept that complexly exposed by a person physical health, psychological state, level of independence, social communication and relationships with the environment (WHOQOL, 1997). It is a subjective concept, showing the relationship between health and quality of life.

Health is an important element of quality of life, but there is not the only determinant of the quality of life. Everyone realizes the quality of life distinctively, depending of age, social status, education, traditions and personal values. Not all people are able to adapt equally to the social, economic, environmental and other continuous operations and factors, changes, so of that 
increasing the gap between the different options and social status groups. And this has an impact on both: health and quality of life.

Quality of life - important whole health system area which requiring substantial adjustment of priorities and reallocation esources in health care. It is necessary to allow welfare for recipients with disabilities or chronic diseases to improve their quality of life too. Even the person who is disabled quality of life can be good.

The quality of life determines social disparities too. This problem exists not only between countries but also within the country, thus the social exclusion is becoming an important in shaping the country's policy. People of lower socioeconomic groups are more exposed to risk factors. To these groups belongs disabled people, especially should be addressed to the mind and mental disabilities and their families.

Of analysis of materials above and the numerous assumptions, the main aim of the possible research and discussions - to find an answer to the arrises question: the path - integration and social status improvement in the society through music therapy - leads to quality of life related values - human dignity, self-esteem and self- realization promotion for adult persons with mental disabilities and how it works?

Object of research - individuals with moderate to profound intellectual disability optimization of the quality of life through music / art therapy techniques.

The aim of the research is to investigate adults with intellectual disabilities life quality optimization in the context of music therapy methods and techniques.

Research methods: 1) theoretical: analysis of scientific literature; 2) empirical: questionnaire, interviews with persons with disabilities, comparative analysis.

\section{Theoretical guidelines}

Precise definition of the term „quality of life" is not easy, because the each person is unique, with a distinctive system of values, needs and opportunities. To select the measure of the quality of life most versatile factors, but the main factors are: individual personal health (physical and mental, and social), the need to communicate and realize their potential in the surrounding environment. Satisfaction of both the disabled and the 'healthy' shows and describes the quality of living. C. Sutton (Sutton, 1999), A. Bakk and K. Grunewald (Baka, Grunevalds, 1998), I. Prudnikova (Prudņikova, 2012) and other scientists recognize and affirms in the researches that people with intellectual disabilities need to realize specific needs, then their quality of life would be optimal in the scop of their abilities. 
These persons who have some form of disability and do not meet the community's standards of communication are still not acceptable. This is especially for people with moderate to profound intellectual disability. This setting determines from the Soviet era shaped public opinion about the fact that all the inhabitants in SU are healthy people. People with intellectual disabilities have been isolated from the society in special closed institutions (pensions), and their existence was known only for short cirle of people /specialists. This occurence J. Ruškus (Ruškus, 2001) is called as „social capsulization phenomenon". Attitude change has been observed towards people with intellectual disabilities that initially from medical problem turn into pedagogic and psychological problem (Prudnikova, 2012). From nowadays was done a lot of changes in laws and real life situations but we have situation that the public does not know how to deal with people with such kind disabilities. Citizens are afraid of them, ignored or even openly mocking. However, the approach to disability and disabled people must change, the expansion of democracy and tolerance ideas in the world are acceptable in Lithuania too what we can find in The Act Equal Opportunity (2005). Socialization problems are solving in G.Kvieskienè (Kvieskienė, 2003), C. Cymru (Cymru, 2000), J. Ruškus (Ruškus, 2002) researches.

For optimization quality of life of people with disabilities are three very important indicators to personal self-concept, self-development and selfexpression which develops other indicators: integration into society, socialization and self-realization.

J. Ruškus (Ruškus, 2002, p. 123) provides such indicators pertaining quality of life of persons with disabilities:

- health: physical and mental health status;

- mental condition, mental disorder;

- the financial situation of the individual;

- living conditions: environmental characteristics, suitability for the individual;

- family: family influence on the individual;

- $\quad$ social relations: social support (emotional and material) status, social emotional experience, the interpersonal relationship quality in the institution;

- recreation, creativity: the quantity and way of leisure activities or creative activity;

- participation in community activities, quantity of participation, method, or professional / employment activities in the institution or outside institution;

- religion: formal (required) or the free practicing or spiritual activities;

- self-assessment / subjective sense of personal well-being: mental, subjective state of the individual, comprising a common self- 
assessment, satisfaction of the being; optimism and approach to the life;

- individual needs assessment.

Therefore, society should offer appropriate services to people with mental disabilities to optimize quality of life.

Impact of music on human health, activities, and social interaction studied a number of foreign experts as O.Bonde (Bonde, 2001), D.Campbell (Campbell, 2005, 2006), L.O`Gradyand K. McFerran (O`Grady, McFerran, 2007), E. Ruud (Ruud, 2006), G. Deker- Foight (Deker- Foight, 2003).

The problems of socialization of disabled people in Lithuania using art therapy methods as medium are solved V. Aleksienè (Aleksienè, 2005), J. Šinkunienè (Šinkūnienè, 2005). These researchers studied more children and young people with a variety of mental (and complex) disability issues and opportunities to adapy methods of art therapy. R.Brūzga (Brūzga, 2005) and J. Taločkienė - Žebrauskienè (Taločkienè - Žebrauskienė, 2005) wrote about the practical experience and methodology how to organize mentally disabled adults musical activities. Some information about socialization using music can find in A. Gaižutis (Gaižutis, 1998) research.

\section{Results of the research}

In the research process was involved people who participated in the socialcultural activities, events where adult intellectually disabled person show their artistic abilities. Testing was done in Lithuania in Plunge, Telsiai and Klaipeda. During different socio-cultural events were tested 123 respondents. Of them: 62 in Plunge, 38 in Klaipeda and 23 in Telsiai. At the same moment were tested adult 54 intellectually disabled persons (28-64 y.o.). Were organized observations before the music workshop, through music session, after the music workshop. Testing still continues and in this article we would want to present few results.

Using Diagnostic methodology possible to do summary, the majority of customers actively participated in workshops (both: individual and group), was sheerful, good moods. This can be explained by the fact that:

a) the client / customers feel safe during the session;

b) well understood given commands;

c) workshops activities were not impaired freely creative abilities;

d) an assessment of his / her / their creative ,product" unconnected of artistic quality;

e) have possibilities to choose the instrument according to his/her moods or on the basis of own criteria.

In the sessions respondent/s participated passive when was felt deterioration in health. 
Using Empiric methodology were interviewed people involved in various socio-cultural events. How respondents decide what person is mentally disabled shows systematic information in Figure 1.

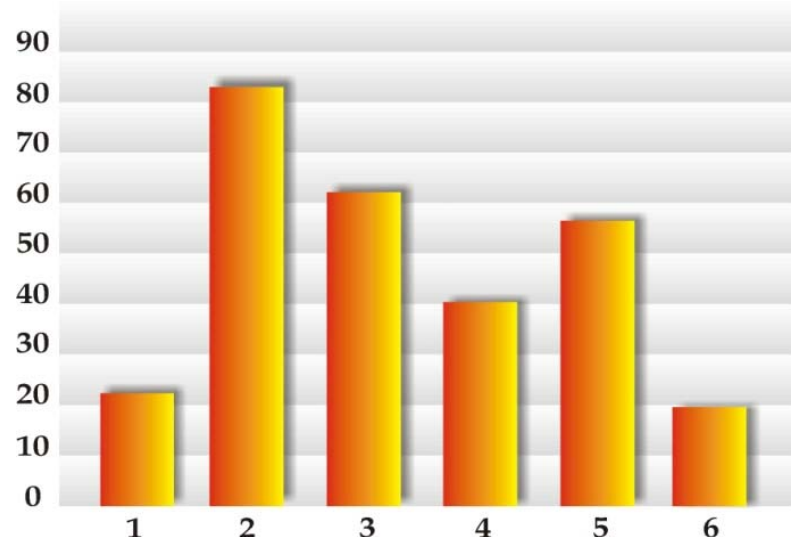

1 of clothing; 2 of the treatment; 3 out of actions; 4 of gestures; 5 of facial features; 6 do not decides until start to communicate

Figure 1. How do you decide that it is mentally disabled person (as long as he does not speak)?

Most of respondents recognized a disabled person from his behavior, actions and facial features $(84,62$, and 58 respondents). That person is mentally disabled from his gesticulation decided 41 respondent. Of clothing about person's disability decided 23 respondents. Not decided until the person started to communicate with the respondent noted 20 patients. These data suggest that people with higher level disabilities apart from other „healthy” because of a long time formed the concept of society and attitudes about the behavior and actions of mentally disabled in a public place.

Respondents were asked how they feel are the most important or disabled their integration process, more specifically, communication with „normal” people. The following results were obtained (Figure 2):

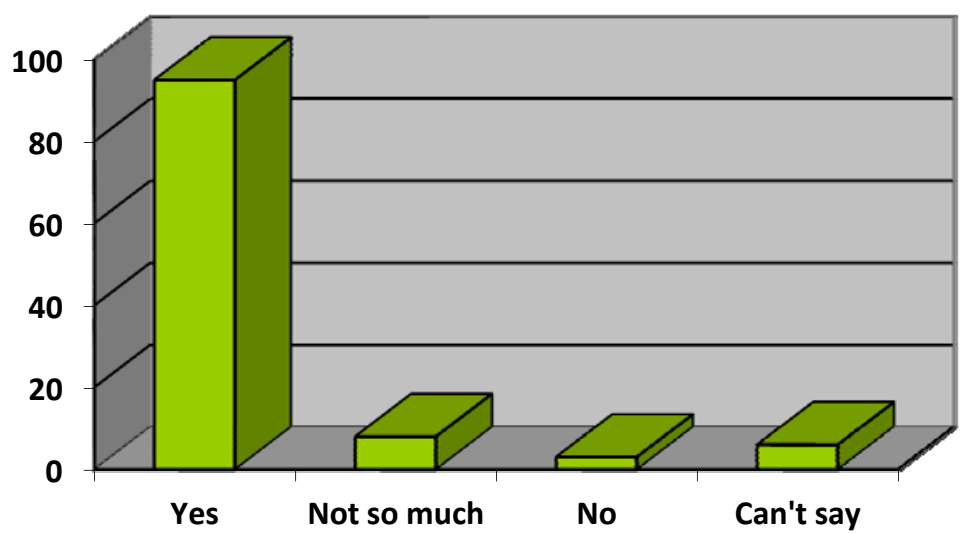

Figure 2. Are there important mentally disabled people with communication „healthy”? 
It means that most of respondents agree that communication as social integration tool is realy importnat for intellectualy disabled people.

Respondents were given the question „Are cultural - artistic activities help people feel in the same levels like ",healthy” ,do such activities develope their self-esteem, change communication skills, independence and understanding about their environment, behavior?" Replies are formated Figure 3.
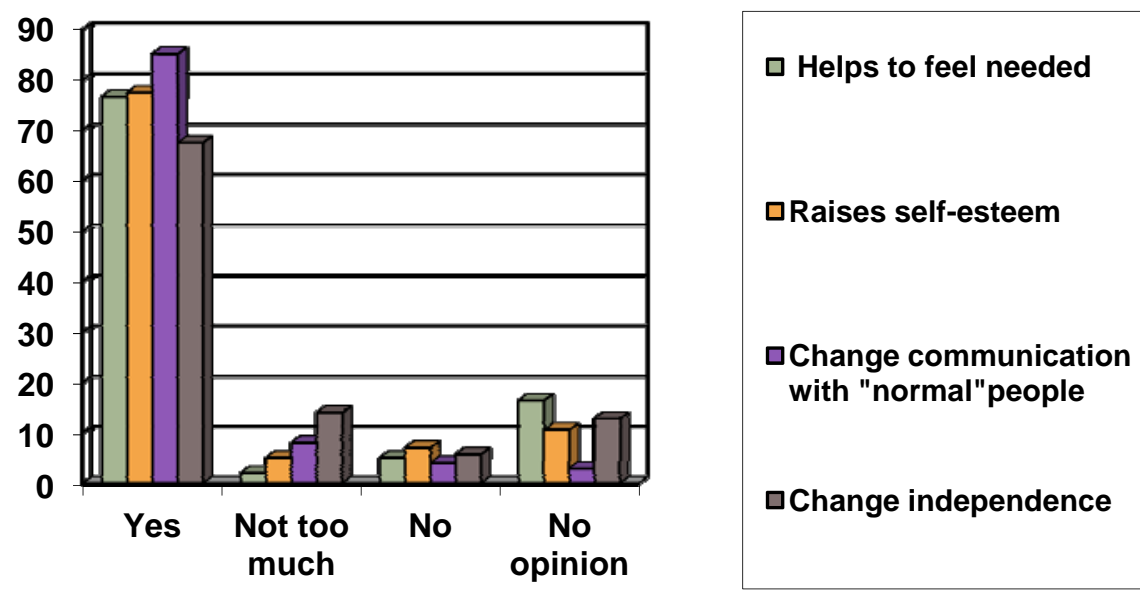

Figure 3. Are cultural - artistic activities help people feel in the same levels like „healthy"

The majority of the respondents answered YES to submited questions (respectively $95.7 \%, 87 \%, 78.9 \%$ and $76 \%$ of respondents). Persons who participated in the study recognize that cultural - artistic activities assist for intellectually disabled persons to feel as equal with „healthy” society. It arise personality self-assessment, what accordingly affects in communication and behavioral changes with others, expanding the information about their environment, and give confidence and independence in modified and enlarged but safe space.

\section{Conclusions}

1. Using music therapy the residential core - through conscious communication between therapist and client, bridging the gap between music and life, to strengthen and nurture the inner and the outer world interfaces.

2. Music workshops raising people with disabilities self-awareness, expanding quantitative and qualitative expression capabilities, increasing their self-esteem and enable self-realization through art - cultural activities, socio-cultural projects and contribute effectively integration into society and thus to optimize the quality of life in the limited possibilities.

3. Monitoring analysis confirmed the theoretical arguments that music workshops allows on residents increasing self-confidence, his/her self- 
esteem changing behavior and communication standards, there is need for self-realization through the day to day activities.

4. Public opinion anglysis showed that the need for communication and cooperation between the "healthy” (,normal”) and the disabled is recognized, and welcome in the process of integration through art - cultural activities.

5. Music - cultural activities help and accelerate people with different kind intellectual disability socialization and integration into society.

\section{References}

Aleksinè, V. (2005). Muzikinis neigaliujų ugdymas ir terapijos ǰžvalgos. Neigaliujųmeninis ugdymas. Vilnius: Kronta.

Aleksienè, V. (2005). Muzikos terapija Lietuvoje: situacija, raida, ateities jžvalgos. Neigaliujų meninis ugdymas. Vilnius: Kronta.

Baka, A., Grunevalds, K. (1998). Grāmata par aprūpi. D. Lapsas tulkojums, Rīga: Preses nams.

Bonde, L.O. (2001). Anouncing Special issue on Guided Imagery and Music (GIM). Nordic journal of music therapy. Sandane, no.10 (2)

Campbell, D. (2005). Mocarto muzikos poveikis vaikams. Kaunas: Kalendorius.

Campbell, D. (2006). Mocarto muzikos poveikis. Vilnius:VšI "Vilties oazé".

Gaižutis, A. (1998). Meno sociologija. Vilnius: Alma Litera.

Jurgelènas, A. at al. (2007). Sveikatos socialiné plètra: monografija. Vilnius: Naujoji matrica. Kvieskiene, G. (2003). Pozityvioji socializacija: monografija. Vilnius: VPU.

Lietuvos respublikos Neigaliuju socialinès integracijos istatymas, date version;No I-2044 Vilnius 2008.

Lindströ, B., Henriksson, B. (1996). The essece of existence. On the quality of lifeof children in the Nordic countries. Internationa Journal of Social welfare,5(2): 117-118

Mocevičienè, A. (2007). People with mental disabilities living in pension life quality optimization. Downloaded from http://vddb.library.lt/fedora/get/LT-eLABa0001:E.02 2007 D 20070816 173519-18808/DS.005.0.02.ETD

NationalAntidiscriminationprogrammme.19th of September 2006 No.907. Vilnius.

Oort, F., Visser, M. \& Sprangers, M. (2005). An applicationof structural equation modeling to decent response shifts and true change in quality of life data from cancer patients undergoing invasive surgery. Quality of Life Research, 14(3): 599-609

O'Grady, L., McFerran, K. (2007). Community Music Therapy and Its Relationship to Community Music: Where Does It End? Nordic Journal of Music Therapy No 16 (1).

Piličiauskas, A. (2005). Neigaliuju meninis ugdymas. Metodikos ir terapijos aspektai. Vilnius: Kronta.

Prudņikova, I. (2012). Skolēnu ar vidēji smagiem un smagiem garīgās attīstības traucējumiem praktiskās darbības pieredzes veidošanās speciālajā internātpamatskolā. Rēzekne: Rēzeknes Augstskola.

Rakauskienė, O.G., Servetkienė, V. (2011). Lietuvos gyventoju gyvenimo kokybè dvidešimt metu rinkos ekonomikoje. Monografija. Vilnius: Mykolo Riomerio universiteto leidybos centras

Ruškus, J. (2001). Negalès psichosociologija. Šiaulių universiteto leidykla.

Ruškus, J. (2002). Negales fenomenas: monografija. Vilnius.

Sutton, C. (1999). Socialinis darbas, bendruomenes veikla ir psichologija. VU Specialiosios psichologijos laboratorija 


\section{SOCIETY. INTEGRATION. EDUCATION. Volume III}

Šinkūnienè, J.R. (2005). Muzikinès komunikacijos ugdymo metodinès kryptys. Neigaliuju meninis ugdymas.Vilnius: Kronta.

Taločkien-Žebrauskienė, J. (2005). Muzikos terapija: žiupsnelis norvegu patirties. Neigaliuju meninis ugdymas. Vilnius: Kronta.

The Act Equal Opportunity. $1^{\text {st }}$ fo January 2005. No IX - 1826. Vilnius

WHOQOL - Measuring quality of life (1997). Downloaded from http://www.who.int/ mental_health/media/68.pdf

WHO Library Cataloguing-in-Publication Data: Integrating the response to mental disorders and other chronic diseases in health care systems (2014). Downloaded from http://apps.who.int/iris/bitstream/10665/112830/1/9789241506793_eng.pdf?ua=1

Декер-ФоигтГ. Г. (2003). Введение в музыкотерапию. Питер. 